\title{
STRATEGI MENINGKATKAN KEPUASAN DAN LOYALITAS NASABAH DENGAN OPTIMALISASI KUALITAS PELAYANAN, PENANGAN KOMPLAIN DAN FASILITAS TEKNOLOGI DI BANK MANDIRI SYARIAH CABANG SOLO
}

\author{
Dra. Nunuk Herawati, MM, MH ${ }^{1),}$ Dra. Murni Sulistyowati, $M^{2)}$, \\ ${ }^{1,}$ Dosen Keuangan dan Perbankan STIE AUB Surakarta \\ 2, Dosen S1 Akuntansi STIE AUB Surakarta \\ J1. Mr. Sartono 97Cengklik, Nusukan. Surakarta. \\ e-mail : ${ }^{1)}$ nunukherawati17@gmail.com \\ ${ }^{2)}$ murni_sulistyowati@yahoo.com
}

\begin{abstract}
Abstrak
Penelitian ini bertujuan untuk mengetahui dan menganalisis secara empiris pengaruh Kualitas Pelayanan, Penanganan Komplain, dan Fasilitas Teknologi terhadap Kepuasan Nasabah, untuk mengetahui dan menganalisis secara empiris pengaruh Kualitas Pelayanan, Penanganan Komplain, Fasilitas Teknologi dan Kepuasan Nasabah terhadap loyalitas nasabah di Bank Mandiri Syariah Cabang Solo. Data yang digunakan data primer yang dikumpulkan melalui penyebaran kuesioner kepada nasabah. Data yang diperoleh diuji dengan menggunakan uji validitas, reliabilitas, analisa jalur, uji t, uji F, uji $\mathrm{R}^{2}$, Uji Korelasi.Hasil uji t menunjukkan bahwa VariabelKualitas Pelayanan, Penanganan Komplain, dan Fasilitas Teknologi berpengaruh signifikan terhadap Kepuasan Nasabah di Bank Mandiri Syariah Cabang Solo,Variabel Kualitas Pelayanan, Penanganan Komplain, Fasilitas Teknologi dan Kepuasan Nasabah

berpengaruh signifikan terhadap Loyalitas Nasabah di Bank Mandiri Syariah Cabang Solo. Hasil uji F

menunjukkan bahwa secara bersama-samaVariabel Kualitas Pelayanan, Penanganan Komplain, Fasilitas Teknologi dan Kepuasan Nasabah berpengaruh signifikan terhadap Loyalitas Nasabah di Bank Mandiri Syariah Cabang Solo. Hasil uji $\mathrm{R}^{2}$ menunjukkan nilai total $\mathrm{R}^{2}$ sebesar 0,8872 atau 88,72\%, artinya variable Kualitas Pelayanan, Penanganan Komplain, Fasilitas Teknologi, dan Kepuasan Nasabah mampu menjelaskan variable Loyalitas Nasabah sebesar 88,72\% sisanya sebesar 11,28\% dijelaskan oleh variable lain di luar model seperti : ikatan emosi, Kepercayaan, Kemudahan transaksi.Hasil uji dengan analisa jalur menunjukkan bahwa Kepuasan Nasabah tidak dapat dijadikan sebagai variable intervening pada hubungan Kualitas Pelayanan, Penanganan Komplain, Fasilitas Teknologi terhadap Loyalitas Nasabah. terhadap Loyalitas pelanggan.

Kata kunci :Kualitas Pelayanan, Penanganan Komplain, Fasilitas Teknologi, Kepuasan , Loyalitas Nasabah
\end{abstract}

\begin{abstract}
This study aims to find out and empirically analyze the influence of Service Quality, Complaint

Handling, and Technology Facilities on Customer Satisfaction in Solo Bank Mandiri Syariah, to know and analyze empirically the influence of Service Quality, Complaint Handling, Technology Facilities and Customer Satisfaction on customer loyalty in Bank Mandiri Syariah Solo Branch. The population in this study were customers of Bank Mandiri Syariah Branch Solo. Data used primary data collected through distributing questionnaires to customers. Data obtained were tested using validity, reliability, path analysis, t test, F test, R2 test, Correlation Test. The t-test results show that Service Quality, Complaint Handling, and Technology Facilities Variables have a significant effect on Customer Satisfaction in Solo Branch Bank Mandiri Syariah, Service Quality Variables, Complaint Handling, Technology Facilities and Customer Satisfaction have a significant effect on Customer Loyalty in Bank Mandiri Syariah Solo Branch. The results of the F test showed that together the Service Quality Variables, Complaint Handling, Technology Facilities and Customer Satisfaction had a significant effect on Customer Loyalty in the Bank Mandiri Syariah Branch Solo.The R2 test results showed a total R2 value of 0.8872 or

88.72\%, meaning Service Quality, Complaint Handling, Technology Facilities, and Customer Satisfaction variables were able to explain Customer Loyalty variables amounting to $88.72 \%$ the remaining $11.28 \%$ explained by other variables outside the model such as: emotional bonds, Trust, Ease of transactions. Test results with analysis The pathway shows that Customer Satisfaction cannot be used as an intervening variable in the relationship of Service Quality, Complaint Handling, Technology Facilities to Customer Loyalty. towards customer loyalty.

Keywords: Service Quality, Complaint Handling, Technology Facilities, Satisfaction, Customer Loyalt
\end{abstract}




\section{PENDAHULUAN}

Dunia perbankan sangat penting bagi perekonomian Indonesia, sehinggaada anggapan bahwa bank merupakan nyawa untuk menggerakan rodaperekonomian suatu negara (Kasmir,2004:12), tetapi

"roda" perbankan tidak dapatberjalan dengan baik apabila tidak didukung dengan adanya nasabah. perekonomian Indonesia, pada tahun 1997/1998 dilanda krisis. Sejak krisisekonomi ini, pemerintah melikuidasi 16 bank pada tanggal 1 November 1997,sebagian nasabah mengalami kesulitan mengambil uang tabungan di bank-banktersebut. Persaingan antar bank di Indonesia memunculkan era baru perbankan. Erabaru yang dimaksud adalah era yang dinamis tingkat persaingan bisnisantar perusahaan

semakin ketat baik di pasar domestik maupun pasarinternasional, khususnya persaingan bisnis antar jasa layanan bank. Banyaknyabank menyebabkan persaingan dalam industri perbankan semakin ketat. Masing-masingbank berlomba menarik dana dari masyarakat, baik dengan tawaran hadiahmaupun bunga yang tinggi. Dalam mempersiapkan diri menghadapi persaingantersebut, maka bank-bank harus jeli dalam melihat peluang pasar serta keinginandan kebutuhan dari nasabah. Bank yang ingin berkembang dan mendapatkankeunggulan kompetitif harus dapat memberikan jasa berkualitas dengan biayayang lebih murah, pelayanan yang lebih baik dan dapat memuaskan kebutuhannasabah serta produk yang variatif sehingga timbul loyalitas.

Dalam industri jasa,kualitas pelayanan adalah faktor yang sangat penting karena merupakan suatuProfit Strategy untuk memikat lebih banyak nasabah baru, mempertahankannasabah yang ada, menghindari berpindahnya nasabah dan menciptakankeunggulan khusus.

Penanganan komplain secara konseptual diyakini mampu menciptakan loyalitas nasabah..Konsep kepuasan pelanggan lahir dan mulai dipraktekan dalam dunia usaha baik jasa maupun barang, dan manajemen komplain merupakan unsur penting yang melatarbelakangi ditemukannya konsep dan teori kepuasan pelanggan. Layanan prima (services excellence) kepada nasabah menjadi komponen utama dan nyata untuk industri perbankan pada saat ini (Stauss dan Seidel: 2006).

Kepuasan nasabah antara lain ditentukan oleh kualitas pelayanan, penangan komplain dan fasilitas teknologi yangdikehendaki nasabah, sehingga jaminan kualitas menjadi prioritas utamabagi setiap perusahaan sebagai tolak ukur keunggulan daya saing perusahaantersebut. Kepuasan nasabah akan berdampak untuk ke depannya. Dampak yang dimaksud adalah apakah nasabah tersebut puasakan produk yang digunakan sehingga nasabah tetap memakai produk tersebut.Pemasaran yang dilakukan oleh perusahaan juga berdampak kepada nasabah. Kepuasan dari sisi konsumen dipandang baik apabila memenuhi apa yang mereka harapkan, sebaiknya pelayanan akan dipersepsikan buruk apabila tidak memenuhi yang mereka harapkan (Kotler, 2005: 45). Kepuasan nasabah sebagai pesepsi terhadap produk atau jasa yang telah memenuhi harapannya. Teori consumer behavior menyatakan bahwa kepuasan nasabah adalah perspektif pengalaman konsumen setelah mengkonsumsi atau menggunakan produk atau jasa. (Oliver,2007:65).

Kualitas layanan dalam perusahaan jasa sering dikondisikan sebagai perbandingan antara layanan yang diharapkan dan layanan yang diterima secara nyata.Perusahaan yang mampu memberikan layanan yang baik kepada nasabah atau pelanggannya memiliki peluang terbesar untuk bisa terus dikunjungi oleh pelanggannya (Liu dan Wu 2007). Pada praktik dalam dunia perbankan saat ini, layanan nasabah dimasukkan sebagai salah satu syarat utama dalam upaya untuk memikat calon nasabah atau untuk melayani nasabah yang sudah ada (existing customers).

Penanganan komplain merupakan perwujudan strategi dan taktik perusahaan (bank) dalam menghadapi keungggulan strategi dan taktik pesaing.Penanganan komplain dapat dijadikan instrument penting dalam mengendalikan konflik antara perusahaan dengan nasabah akan ketidakpuasan(Kaudan Loh, 2006). Penanganan komplain oleh bank menjadi alat untuk mendongkrak perolehan profit bank bersangkutan (Straus dan Seidel 2006).

Faktor lain yang mempengaruhi kepuasan nasabah adalah fasilitas teknologi. Fasilitas teknologi merupakan perlengkapan yang memberikan kemudahan kepada para nasabah untuk melaksanakan aktivitas-aktivitasnyasehingga kebutuhan nababah dapat terpenuhi seperti internet banking. Fasilitas teknologi disediakanoleh Bank Mandiri Syariah Cabang Solo sebagai sarana untuk melengkapi dan mendukung aktivitas dalamkelancaran konsumen untuk menikmati pelayanan yang diberikan. Lengkapnyafasilitas berpengaruh terhadap kepuasan nasabah. Hal ini jelas sekali bahwa nasabah akan menuntut kemudahan - kemudahan kepada pihak pemberi jasaberkenaan dengan kebutuhan yang diinginkan oleh nasabah.

Loyalitas adalah respon perilaku/pembelian yang yang bersifat bias dan terungkap secara terusmenerus oleh pengambil keputusan dengan memperhatikansatu atau lebih merek alternative dari sejumlah merek sejenis dan merupakan fungsi prosespsikologis. Namun perlu ditekankan bahwa haltersebut berbeda dengan perilaku beli ulang, loyalitaspelanggan menyertakan aspek perasaan didalamnya, Oleh karena itu konsumen tidak dapat dilepaskan secara independen untuk menetapkan

mutu pelayanan yang baik. Dengan demikian pemenuhan kebutuhan konsumen saja tidak dapat dijadikan ukuran menetapkan kualitas pelayanan terhadap para konsumen. Sebaliknya penetapan mutu pelayanan terhadap konsumen dari sisi para profesional saja, dapat menyebabkan konsumen tidak tertarik dengan produk yang ditawarkan.

Bank Mandiri Syariah merupakan salah satu Bank BUMN di Indonesia yang hidup berdampingan dengan Bank Mandiri Konvensional harus bersaing dengan Bank Konvensional maupun Bank Syariah lainnya dengan mengedepankan konsep pemasaran dan strategi pemasaran.Marketing Research Indonesia (MRI) tentang loyalitas nasabah dan The Best Bank Services Excellence atau layanan prima kepada nasabah menunjukkan bahwa Bank Mandiri Syariah dalam hal layanan dan loyalitas nasabah masih jauh dari 
harapan. Hal tersebut bisa dilihat dari rendahnya peringkat Bank Mandiri Syariah dibanding Bank Mandiri Konvensional hampir di semua sektor layanan nasabah.Fenomena- fenomena inilah yang melatarbelakangi perumusan masalah dalam penelitian ini. Unsur layanan (Service Excellence) dan Indonesian Bank Loyality Index (IBLI) 2008 adalah salah satu tolak ukur penilaian tingkat kepuasan dan loyalitas nasabah perbankan di Indonesia yang dilakukan yang dilakukan oleh majalah Infobank, dalam melakukan penilaian berupa skor, majalah Infobank mengemukakan empat dasar penilaian yang menjadi tolak ukur survei tersebut, yaitu transaction, relationship, partnership dan ownership, penilaian dituangkan dalam prosentase dan semakin besar atau tinggi prosentase penilaian maka akan semakin tinggi peringkat bank tersebut dalam hal layanan prima terhadapnasabah. Hasil survei ini juga menunjukkan bahwa indeks loyalitas sebuah bank akan meningkat apabila bank tersebut bisa meningkatkan indeks partnership dan ownership. Hal ini mengindikasikan bahwa nasabah bukan hanya ingin bertransaksi atau menjalin relasi dengan bank, tetapi juga berupaya menjadi mitra dan bahkan "memiliki" bank tersebut.

Penelitian ini mencoba mengembangkan penelitian sebelumnya dimana bangunan dan rumusan model penelitian in merujuk pada beberapa hasil penelitian seperti studi Oliver (1999); Lyon dan Powers (2004), menyatakan bahwa kualitas layanan merupakan salah satu kunci yang dijadikan pertimbangan kepuasan nasabah, selanjutnya nasabah yang merasa puas akan melakukan pembelian ulang atau pengulangan selanjutnya nasabah tersebut akan bersedia untuk merekomendasikan kepada orang lain. Zeithaml dan Bitner (1996); Liu dan Wu (2007), mengungkapkan beberapa atribut yang merupakan obyek evaluasi konsumen ketika konsumen tersebut mengkonsumsi jasa, yaitu bukti fisik (physical evidence), karyawan (people) dan proses (process). Penanganan komplain dan fasilitas tehnologi merupakan instrumen penting bagi terwujudnya kepuasan dan Loyalitas nasabah bagi dunia perbankan (McCole 2004; Ngai et al.,2007).

Tujuan penelitian ini adalah untuk mengetahui dan menganalisis secara empiris pengaruh Kualitas Pelayanan, Penanganan Komplain, dan Fasilitas Teknologi terhadap Kepuasan Nasabah, untuk mengetahui dan menganalisis secara empiris pengaruh Kualitas Pelayanan, Penanganan Komplain, Fasilitas Teknologi dan Kepuasan Nasabah terhadap loyalitas nasabah di Bank Mandiri Syariah Cabang Solo.

\section{METODE PENELITIAN}

Penelitian ini merupakan penelitian kuantitatif dengan metode survei dan mengambil sampel

100 responden dengan menggunakan Accidental sampling. Objek penelitian ini adalah nasabah di Bank Mandiri Syariah Cabang Solo.Metode pengumpulan data dilakukan dengan kuesioner dan studi pustaka. Kusioner dilakukan dengan menyebar angket berupa daftar pertanyaan mengenai masalah yang akan diteliti dengan beberapa variabel antara lain kepuasan pelanggan, loyalitas pelanggan, Kualitas Pelayanan, Penanganan Komplain, dan Fasilitas Teknologi Metode analisis data menggunakan uji validitas, reliabilitas, analisa jalur, uji t, uji F, uji $\mathrm{R}^{2}$, Uji Korelasi.

\section{HASIL PENELITIAN}

\section{Deskripsi Data}

Penelitian ini dilakukan pada nasabah di Bank Mandiri Syariah Cabang Solo Berdasarkan hasil kuesioner 100 eksemplar/responden dapat dideskripsikan sebagai berikut :

Berdasarkan jenis kelamin mayoritas responden adalah perempuan sebanyak $71 \%$ dan laki-lakinya sebesar $29 \%$ dari total responden.

Responden berdasarkan umur menunjukkan mayoritas responden memiliki pekerjaan pegawai swasta sebesar 34\%, diikuti PNS/TNI/POLRI sebesar 25\%,pelajar/mahasiswa sebesar 20\%, wiraswasta sebanyak $13 \%$ dan lain-lain sebesar $8 \%$.

Berdasarkan pekerjaan responden, mayoritas responden memiliki pekerjaan pegawai swasta sebesar 58\%, diikuti pelajar/mahasiswa sebesar $25 \%$, Ibu Rumah Tangga sebesar 9\%, PNS/TNI/POLRI sebesar 6\%, wiaswasta $2 \%$.

\section{ANALISIS DATA}

\section{Uji Instrumen Penelitian}

Uji validitas

Uji validitas dalam penelitian ini mengunakan teknik korelasi product moment. Suatu item dikatakan valid jika nilai probabilitas $<0,05$, dan tidak valid jika nilai probabilitas $>0,05$. 


\begin{tabular}{|c|c|c|c|c|}
\hline \multicolumn{5}{|c|}{ Hasil Uji Validitas } \\
\hline No & Indikator & rhitung & rtabel & Keterangan \\
\hline \multirow[t]{6}{*}{1} & Kualitas Pelayanan (X1) & & & \\
\hline & $\mathrm{X}_{1-1}$ & 0,510 & 0,194 & Valid \\
\hline & $X_{1 \_2}$ & 0,792 & 0,194 & Valid \\
\hline & $X_{1 \_} 3$ & 0,364 & 0,194 & Valid \\
\hline & $X_{1-4}$ & 0,729 & 0,194 & Valid \\
\hline & $\mathrm{X}_{1-5}$ & 0,562 & 0,194 & Valid \\
\hline \multirow[t]{4}{*}{2} & Penanganan Komplain $\left(\mathrm{X}_{2}\right)$ & & & \\
\hline & $\mathrm{X}_{2} \_1$ & 0,799 & 0,194 & Valid \\
\hline & $\mathrm{X}_{2} \_2$ & 0,720 & 0,194 & Valid \\
\hline & $\mathrm{X}_{2} 3$ & 0,814 & 0,194 & Valid \\
\hline \multirow[t]{6}{*}{3} & Fasilitas Teknologi (X3) & & & \\
\hline & $\mathrm{X}_{3 \_} 1$ & 0,651 & 0,194 & Valid \\
\hline & $X_{3 \_} 2$ & 0,785 & 0,194 & Valid \\
\hline & $X_{3 \_} 3$ & 0,603 & 0,194 & Valid \\
\hline & $X_{3-4}$ & 0,557 & 0,194 & Valid \\
\hline & $X_{3 \_} 5$ & 0,785 & 0,194 & Valid \\
\hline \multirow[t]{6}{*}{4} & Kepuasan nasabah (Y1) & & & \\
\hline & $\mathrm{Y}_{1 \_1}$ & 0,563 & 0,194 & Valid \\
\hline & $\mathrm{Y}_{1 \_2}$ & 0,567 & 0,194 & Valid \\
\hline & $Y_{1 \_3}$ & 0,489 & 0,194 & Valid \\
\hline & $Y_{1 \_4}$ & 0,512 & 0,194 & Valid \\
\hline & $\mathrm{Y}_{1 \_} 5$ & 0,565 & 0,194 & Valid \\
\hline \multirow[t]{6}{*}{5} & Loyalitas Nasabah(Y2) & & & \\
\hline & $\mathrm{Y}_{2 \_} 1$ & 0,278 & 0,194 & Valid \\
\hline & $\mathrm{Y}_{2 \_2}$ & 0,408 & 0,194 & Valid \\
\hline & $\mathrm{Y}_{2 \_3}$ & 0,365 & 0,194 & Valid \\
\hline & $\mathrm{Y}_{2}{ }_{4}$ & 0,508 & 0,194 & Valid \\
\hline & $\mathrm{Y}_{2 \_5}$ & 0,409 & 0,194 & Valid \\
\hline
\end{tabular}

Sumber: data yang diolah,2018

Hasil dari item-item pertanyaaan semua valid karena mempunyai nilai $\mathrm{r}_{\text {hitung }}$ lebih besar dari $\mathrm{r}_{\text {tabel }}(0,194)$.

\section{Uji Reliabilitas}

Reliabilitas dari suatu pengukuran mencerminkan apakah suatu pengukuran terbebas dari kesalahan (error) sehingga memberikan hasil pengukuran yang konsisten pada kondisi masing-masing butir dalam instrumen (Sekaran, 2006:67). Dalam hal ini, reliabilitas diukur dengan alat ukur Cronbach's alpha> 0,60 maka instrumen tersebut reliabel, dan apabila < 0,60 instrumen tersebut tidak reliabel (Nunnaly dalam Ghozali, 2005:43)

$\underline{\text { Uji Reliabilitas }}$

\begin{tabular}{|l|c|l|l|}
\hline \multicolumn{1}{|c|}{ Variabel } & $\begin{array}{c}\text { Cronbach's } \\
\text { Alpha }\end{array}$ & Ketentuan & Keterangan \\
\hline Kualitas Pelayanan $\left(\mathrm{X}_{1)}\right.$ & 0,792 & Nilai cronbach & Reliabel \\
Penanganan Komplain $\left(\mathrm{X}_{2}\right)$ & 0,885 & alpha > 0,60 & Reliabel \\
Fasilitas Teknologi $\left(\mathrm{X}_{3}\right)$ Kepuasan & 0,850 & (sekaran, 2010:87) & Reliabel \\
Nasabah $\left(\mathrm{Y}_{1}\right)$ & 0,768 & & Reliabel \\
Loyalitas Nasabah $\left(\mathrm{Y}_{2}\right)$ & 0,639 & & Reliabel \\
\hline
\end{tabular}

Sumber : Data yang diolah 2018

Dari hasil pengujian reliabilitas menunjukkan bahwa cronbach alpha seluruh variabel lebih besar dibandingkan dengan kriteria yang dipersyaratkan atau nilai kritis (rule of tumb) sebesar 0,6 sehingga dapat dikatakan bahwa butir-butir pernyataan seluruh variabel 
dalam keadaan reliabel.

\section{Uji Linieritas}

Uji linieritas merupakan langkah untuk mengetahui status linier tidaknya suatu distribusi sebuah data penelitian. Hasil yang diperoleh melalui uji linieritas akan menentukan teknik analisis regresi yang akan digunakan. Jika hasil uji linieritas merupakan data yang linier maka digunakan analisis regresi

linier. Sebaliknya jika hasil uji linieritas merupakan data yang tidak linier maka analisis regresi yang akan digunakan non linier

Hasil Uji Linieritas

Model Summary ${ }^{b}$

\begin{tabular}{|l|l|l|l|l|}
\hline Model & \multicolumn{1}{|c|}{$\mathrm{R}$} & $\mathrm{R}$ Square & $\begin{array}{l}\text { Adjusted } \\
\mathrm{R} \text { Square }\end{array}$ & $\begin{array}{l}\text { Std. Error of the } \\
\text { Estimate }\end{array}$ \\
\hline 1 &, $019^{\mathrm{a}}$ &, 000 &,- 042 &, 98968612 \\
\hline
\end{tabular}

a. Predictors: (Constant), Kepuasan Nasabah, Fasilitas Teknologi, Penanganan Komplain, Kualitas Pelayanan

b. Dependent Variable: Unstandardized Residual

Dari hasil uji linieritas menunjukkan nilai $R^{2}$ sebesar 0,000 dengan jumlah sampel 100, besarnya nilai $\mathrm{c}^{2}$ hitung $=100 \times 0,000=0$ sedangkan nilai $\mathrm{c}^{2}$ tabel sebesar 123,86 Nilai $\mathrm{c}^{2}$ hitung $<\mathrm{c}^{2}$ tabel jadi dapat disimpulkan bahwa model yang benar adalah model linier.

\section{Analisis Regresi Jalur}

\section{Persamaan Pertama}

a. Persamaan Pertama

$Y_{1}=0,897 X_{1}-0,087 X_{2}+0,090 X_{3}$

Sig $(0,000)^{* *} \quad(0,006) * * \quad(0,044) * *$

Ket :

$\mathrm{Y}_{1} \quad=$ Kepuasan Nasabah

$\mathrm{X}_{1} \quad=$ kualitas Pelayanan

$\mathrm{X}_{2}=$ Penanganan Komplain

$\mathrm{X}_{3} \quad=$ Fasilitas Teknologi

$* * \quad=$ Signifikansi

Hasil regresi persamaan pertama menunjukkan Kualitas Pelayanan, Penanganan Komplain,Fasilitas Teknologi berpengaruh positif terhadap Kepuasan pelanggan.

b. Persamaan Kedua

$Y_{2}=0,382 X_{1}+0,078 X_{2}+0,144 X_{3}+0,339 X_{4}$

Sig $(0,001)^{* *}(0,031) * * \quad(0,005) * *(0,003) * *$

Ket :

$\mathrm{Y}_{2} \quad=$ Loyalitas Nasabah

$\mathrm{X}_{1} \quad=$ Kualitas Pelayanan

$\mathrm{X}_{2} \quad=$ Penanganan Komplain

$\mathrm{X}_{3} \quad=$ Fasilitas Teknologi

$\mathrm{X}_{4} / \mathrm{Y}_{1} \quad=$ Kepuasan Pelanggan

$* * \quad=$ Signifikansi

Hasil regresi persamaan kedua menunjukkan Kualitas Pelayanan, Penanganan Komplain,Fasilitas Teknologi, Kepuasan pelanggan berpengaruh positif terhadap loyalitas nasabah. 


\section{Uji t}

\section{Persamaan Pertama}

$\underline{\text { Hasil Uji t Persamaan Pertama }}$

Coefficients

\begin{tabular}{|c|c|c|c|c|c|}
\hline \multirow[b]{2}{*}{ Model } & \multicolumn{2}{|c|}{$\begin{array}{l}\text { Unstandardized } \\
\text { Coefficients }\end{array}$} & \multirow{2}{*}{\begin{tabular}{|c|}
$\begin{array}{l}\text { Standardized } \\
\text { Coefficients }\end{array}$ \\
Beta \\
\end{tabular}} & \multirow[b]{2}{*}{$\mathrm{t}$} & \multirow[b]{2}{*}{ Sig. } \\
\hline & B & Std. Error & & & \\
\hline \multirow{4}{*}{$\begin{array}{l}1 \quad \text { (Constant) } \\
\text { Kualitas Pelayanan Penanganan } \\
\text { Komplain Fasilitas Teknologi }\end{array}$} & 1,315 & 1,383 & & ,951 & ,344 \\
\hline & ,897 &, 040 & ,918 & 22,192 &, 000 \\
\hline &,- 087 &, 031 &,- 116 & $-2,799$ & 006 \\
\hline &, 090 &, 044 & \multicolumn{2}{|c|}{$, 084 \mid 2,036$} &, 044 \\
\hline
\end{tabular}

a. Dependent Variable: Kepuasan Nasabah

Dari Uji t pada persamaan Pertama dapat disimpulkan bahwa Kualitas Pelayanan, Penanganan Komplain, fasilitas teknologi berpengaruh signifikan terhadap Kepuasan Nasabah . Hal ini dapat dilihat dari nilai signifikansi masing-masing variabel <0,05.

\section{Persamaan Kedua}

Uji t pada persamaan Kedua dapat dilihat dalam table di bawah ini, dapat dijelaskan hal-hal sebagai berikut :

\section{$\underline{\text { Hasil Uji t Persamaan Kedua }}$}

Coefficients ${ }^{\mathrm{a}}$

\begin{tabular}{|c|c|c|c|c|c|}
\hline \multirow[b]{2}{*}{ Model } & \multicolumn{2}{|c|}{$\begin{array}{l}\text { Unstandardized } \\
\text { Coefficients }\end{array}$} & \multirow{2}{*}{\begin{tabular}{|c|}
$\begin{array}{l}\text { Standardized } \\
\text { Coefficients }\end{array}$ \\
Beta \\
\end{tabular}} & \multirow[b]{2}{*}{$\mathrm{t}$} & \multirow[b]{2}{*}{ Sig. } \\
\hline & $\mathrm{B}$ & Std. Error & & & \\
\hline \multirow{5}{*}{$\begin{array}{l}1 \quad \text { (Constant) } \\
\text { Kualitas Pelayanan Penanganan } \\
\text { Komplain Fasilitas Teknologi } \\
\text { Kepuasan Nasabah }\end{array}$} & 2,270 & 1,526 & & 1,488 &, 140 \\
\hline & ,382 &, 110 &, 459 & 3,478 &, 001 \\
\hline & ,078 & ,036 &, 122 & 2,191 &, 031 \\
\hline & ,144 & ,050 &, 158 & 2,898 &, 005 \\
\hline & ,339 & ,112 & ,397 & 3,020 &, 003 \\
\hline
\end{tabular}

a. Dependent Variable: Loyalitas Nasabah

Dari Uji t pada persamaan Kedua dapat disimpulkan bahwa Kualitas Pelayanan, Penanganan Komplain, fasilitas teknologi dan Kepuasan Nasabah berpengaruh signifikan terhadap Loyalitas Nasabah. Hal ini dapat dilihat dari nilai signifikansi masing-masing variabel $<0,05$.

\section{Uji F}

\section{Uji F persamaan pertama}

Uji $\mathrm{F}$ dilakukan untuk mengetahui signifikansi pengaruh variabel independen terhadap variabel dependen secara bersamasama. Dikatakan berpengaruh signifikan apabila nilai sig $<0,05$.

\section{$\underline{\text { Hasil Uji F persamaan pertama }}$}

\section{ANOVA}

\begin{tabular}{|c|c|c|c|c|c|}
\hline Model & $\begin{array}{l}\text { Sum of } \\
\text { Squares }\end{array}$ & df & Mean Square & $\mathrm{F}$ & Sig. \\
\hline $1 \quad$ Regression & 401,314 & & 3133,771 & 164,797 &, $000^{\mathrm{a}}$ \\
\hline Residual & 77,926 & & 96,812 & & \\
\hline Total & 479,240 & & 99 & & \\
\hline
\end{tabular}

a. Predictors: (Constant), Fasilitas Teknologi, Kualitas Pelayanan, Penanganan Komplain

b. Dependent Variable: Kepuasan Nasabah 
Hasil uji secara serempak (Uji F) pada persamaan pertama diketahui besarnya nilai $\mathrm{F}=164,797$ signifikansi $0,000<0,05$. Sehingga dapat disimpulkan secara bersama-sama variabel Kualitas Pelayanan, Fasilitas Teknologi, Penanganan Komplain berpengaruh signifikan terhadap Kepuasan Nasabah.

\section{Hasil Uji F Persamaan Kedua}

Hasil perhitungan Uji F Persamaan Kedua dapat dijelaskan sebagai berikut:

\section{Uji F Persamaan Kedua}

\section{ANOVA}

\begin{tabular}{|c|c|c|c|c|c|}
\hline Model & $\begin{array}{l}\text { Sum of } \\
\text { Squares }\end{array}$ & df & Mean Square & $\mathrm{F}$ & Sig. \\
\hline Regression & 255,668 & 4 & 63,917 & 65,234 & ,000a \\
\hline Residual & 93,082 & 95 & 980 & & \\
\hline Total & 348,750 & 99 & & & \\
\hline
\end{tabular}

a. Predictors: (Constant), Kepuasan Nasabah, Fasilitas Teknologi, Penanganan Komplain, Kualitas Pelayanan

b. Dependent Variable: Loyalitas Nasabah

Hasil uji secara serempak (Uji F) pada persamaan kedua diketahui besarnya nilai $F=65,234$ signifikansi 0,000<0,05. Sehingga dapat disimpulkan secara bersama-sama variabel Kualitas Pelayanan, Fasilitas Teknologi, Penanganan Komplain dan Kepuasan Nasabahberpengaruh signifikanterhadap Loyalitas Nasabah.

\section{Koefisien Determinasi}

\section{Koefisien Determinasi Persamaan 1.}

Hasil Uji Determinasi Persamaan 1

Model Summary

\begin{tabular}{|l|l|l|l|l|}
\hline Model & \multicolumn{1}{|c|}{$\mathrm{R}$} & R Square & $\begin{array}{l}\text { Adjusted } \\
\text { R Square }\end{array}$ & $\begin{array}{l}\text { Std. Error of the } \\
\text { Estimate }\end{array}$ \\
\hline 1 &, $915^{\mathrm{a}}$ &, 837 &, 832 &, 901 \\
\hline
\end{tabular}

a. Predictors: (Constant), Fasilitas Teknologi, Kualitas

Pelayanan, Penanganan Komplain

Uji $R^{2}$ didapatkan hasil sebesar 0,387

Koefisien Determinasi Persamaan 2.

$\underline{\text { Hasil Uji Determinasi Persamaan } 2}$

Model Summary

\begin{tabular}{|l|l|l|l|l|}
\hline Model & $\mathrm{R}$ & R Square & $\begin{array}{l}\text { Adjusted } \\
\text { R Square }\end{array}$ & $\begin{array}{l}\text { Std. Error of the } \\
\text { Estimate }\end{array}$ \\
\hline 1 &, $856^{\mathrm{a}}$ &, 733 &, 722 &, 990 \\
\hline
\end{tabular}

a. Predictors: (Constant), Kepuasan Nasabah, Fasilitas

Teknologi, Penanganan Komplain, Kualitas Pelayanan

Uji $\mathrm{R}^{2}$ didapatkan nilai $\mathrm{R}$ square sebesar 0,733

Berdasarkan Berdasarkan tabel IV.15 dan Tabel IV.16 tersebut di atas maka dapat dihitung nilai $\mathrm{R}^{2}$ total dengan cara (Ghozali,20005:161):

1). Menghitung $\mathrm{e}_{1}$ pada persamaan struktur 1 dengan cara : $\sqrt{ }\left(1-\mathrm{R}^{2}\right)=\quad \sqrt{ }(1-0,837)=0,404$

2). Menghitung $e_{2}$ pada persamaan struktur 2 dengan cara $: \sqrt{ }\left(1-R^{2}\right)=\sqrt{ }(1-0,722)=0,527$

3). Total $R^{2}=\sqrt{1}-\left(\mathrm{e}_{1} \times \mathrm{e}_{2}\right)=\sqrt{ } 1-(0,404 \times 0,527)=0,8872$ Kesimpulan untuk total $\mathrm{R}^{2}$ pada model yang digunakan adalah 0,8872 atau $88,72 \%$, artinya model dengan persamaan ini variable independen (Kualitas Pelayanan, Penanganan Komplain, Fasilitas Teknologi dan Kepuasan Nasabah) mampu menjelaskan variable dependen (Loyalitas Nasabah) sebesar 88,72\%, sisanya sebesar 
11,28\% dijelaskan oleh variable lain di luar model seperti : ikatan emosi, Kepercayaan, Kemudahan transaksi

Korelasi antar variable

Korelasi antar variable dapat dilihat pada tabel di bawah ini:

$\underline{\text { Hasil Korelasi antar Variabel }}$

Correlations

\begin{tabular}{|c|c|c|c|c|c|c|c|}
\hline & & $\begin{array}{l}\text { Kualitas } \\
\text { Pelayanan }\end{array}$ & $\begin{array}{l}\text { Penanganan } \\
\text { Komplain }\end{array}$ & $\begin{array}{l}\text { Fasilitas } \\
\text { Teknologi }\end{array}$ & $\begin{array}{l}\text { Kepuasan } \\
\text { Nasabah }\end{array}$ & $\begin{array}{l}\text { Loyalitas } \\
\text { Nasabah }\end{array}$ & \\
\hline $\begin{array}{l}\text { Kualitas Pelayanan } \\
\text { Sig. (2-tailed) N }\end{array}$ & Pearson Correlation & $\begin{array}{r}1 \\
100\end{array}$ & \begin{tabular}{|r}
, 085 \\
, 400 \\
100
\end{tabular} & $\mid \begin{array}{ll} & -, 064 \\
525^{-} & 100\end{array}$ & $\begin{array}{r}, 903^{* *} \\
, 000 \\
100 \\
\end{array}$ & $\left\{\begin{array}{l}, 817^{*} \\
000 \\
100\end{array}\right.$ & \\
\hline $\begin{array}{l}\text { Penanganan Komplain } \\
\text { Sig. (2-tailed) } N\end{array}$ & Pearson Correlation & $\begin{array}{l}085 \\
400 \\
100\end{array}$ & $\begin{array}{r}1 \\
100\end{array}$ & $\begin{array}{l}-, 103 \\
100\end{array}$ & $\begin{array}{r}-, 047 \\
, 644 \\
100 \\
\end{array}$ & $4, \begin{array}{l}126 \\
211 \\
100\end{array}$ & \\
\hline $\begin{array}{l}\text { Fasilitas Teknologi } \\
\text { Sig. (2-tailed) N }\end{array}$ & Pearson Correlation & $\begin{array}{l}-, 064 \\
525 \\
100\end{array}$ & $\begin{array}{r}-, 103 \\
, 309 \\
100\end{array}$ & 1 & \begin{tabular}{r|}
, 037 \\
, 713 \\
100 \\
\end{tabular} & $3 \begin{array}{l}131 \\
195 \\
100\end{array}$ & \\
\hline $\begin{array}{l}\text { Kepuasan Nasabah } \\
\text { Sig. (2-tailed) N }\end{array}$ & Pearson Correlation & $\begin{array}{l}903^{* *} \\
, 000 \\
100\end{array}$ & $\begin{array}{r}-, 047 \\
, 644 \\
100 \\
\end{array}$ & $\begin{array}{l}.037 \\
713 \\
100 \\
\end{array}$ & $\begin{array}{r}1 \\
100 \\
\end{array}$ & $\left\{\begin{array}{l}, 811^{\star *} \\
, 000 \\
100\end{array}\right.$ & \\
\hline $\begin{array}{l}\text { Loyalitas Nasabah } \\
\text { Sig. (2-tailed) N }\end{array}$ & Pearson Correlation & $\begin{array}{l}817^{*} \\
000 \\
100\end{array}$ & $\begin{array}{r}, 126 \\
, 211 \\
100\end{array}$ & $\begin{array}{l}131 \\
195 \\
100\end{array}$ & $\begin{array}{r}, 811^{* *} \\
, 000 \\
100\end{array}$ & & 100 \\
\hline
\end{tabular}

${ }^{* *}$. Correlation is significant at the 0.01 level (2-tailed).

Dari tabel di atas dapat disimpulkan sebagai berikut :

a. Korelasi antara Kualitas Pelayanan dengan kepuasan nasabah menunjukkan angka korelasi sebesar 0,903 dengan nilai signifikasi sebesar 0,000 < 0,05 sehingga dapat disimpulkan bahwa Kualitas Pelayanan mempunyai hubungan signifikan dan mempunyai korelasi sangat kuat dengan kepuasan nasabah, karena korelasinya antara 0,80-1,000.

b. Korelasi antara Penanganan Komplain dengan Kepuasan Nasabah menunjukkan angka korelasi sebesar $-0,047$ dengan nilai signifikasi sebesar $0,644>0,05$ sehingga dapat disimpulkan bahwa Penanganan Komplain mempunyai hubungan tidak signifikan dan mempunyai korelasi sangat lemah dengan kepuasan nasabah, karena korelasinya antara $0,000-0,199$.

c. Korelasi antara fasilitas teknologi dengan Kepuasan Nasabah menunjukkan angka korelasi sebesar 0,037 dengan nilai signifikasi sebesar 0,713> 0,05 sehingga dapat disimpulkan bahwa Fasilitas Teknologi mempunyai hubungan tidak signifikan dan mempunyai korelasi lemah dengan kepuasan nasabah, karena korelasinya antara 0,00 - 0,199.

d. Korelasi antara kualitas Pelayanan dengan Loyalitas Nasabah menunjukkan angka korelasi sebesar 0,817 dengan nilai signifikasi sebesar 0,000 $<0,05$ sehingga dapat disimpulkan bahwa Kualitas Pelayanan mempunyai hubungan signifikan dan mempunyai korelasi sangat kuat dengan Loyalitas nasabah, karena korelasinya antara 0,80 - 1,000.

e. Korelasi Antara Penanganan Komplain dengan Loyalitas Nasabah menunjukkan angka korelasi sebesar 0,126 dengan nilai signifikasi sebesar 0,211>0,05 sehingga dapat disimpulkan bahwa Penanganan Komplain mempunyai hubungan tidak signifikan dan mempunyai korelasi lemah dengan Loyalitas Nasabah, karena korelasinya antara 0,20 0,399 .

f. Korelasi antara Fasilitas Teknologi dengan Loyalitas Nasabah menunjukkan angka korelasi sebesar 0,131 dengan nilai signifikasi sebesar 0,195> 0,05 sehingga dapat disimpulkan bahwa Fasilitas Teknologi mempunyai hubungan tidak signifikan dan mempunyai korelasi sangat lemah dengan Loyalitas Nasabah, karena korelasinya antara 0,00 0,199 .

g. Korelasi antara Kepuasan Nasabah dengan Loyalitas Nasabah menunjukkan angka korelasi sebesar 0,811 dengan nilai signifikasi sebesar 0,000 < 0,05 sehingga dapat disimpulkan bahwa Kepuasan nasabah mempunyai hubungan signifikan dan mempunyai korelasi sangat kuat dengan Loyalitas Nasabah karena korelasinya antara 0,80-1,000. 


\section{Pengaruh langsung, pengaruh tidak langsung dan pengaruh total}

Pengaruh langsung, pengaruh tidak langsung dan pengaruh total adalah sebagai berikut :

\section{Pengaruh langsung}

1). Hasil uji dengan model persamaan regresi kedua menunjukkan bahwa Kualitas Pelayanan mempunyai standardized coefficients beta sebesar 0,382 dengan signifikansi 0,001 artinya bahwa $\mathrm{K}$ ualitas Pelayanan mempunyai pengaruh langsung terhadap Loyalitas Pelanggan.

2). Hasil uji dengan model persamaan regresi kedua menunjukkan bahwa Penanganan Komplain mempunyai standardized coefficients beta sebesar 0, 078 dengan signifikansi 0,031 artinya bahwa Penanaganan Komplain mempunyai pengaruh langsung terhadap Loyalitas Pelanggan.

3). Hasil uji dengan model persamaan regresi kedua menunjukkan bahwa Fasilitas Teknologi mempunyai standardized coefficients beta sebesar 0,144 dengan signifikansi 0,005Fasilitas Teknologi mempunyai pengaruh langsung terhadap Loyalitas Pelanggan.

\section{Pengaruh tidak langsung}

1). Pengaruh tidak langsung variable Kualitas Pelayanan terhadap Loyalitas Nasabah melalui KepuasanNasabah.

Hasil uji dengan model persamaan regresi pertama dan kedua menunjukkan bahwa pengaruh Kualitas Pelayanan terhadap Kepuasan Pelanggan sebesar 0,897, sedangkan pengaruh Kepuasan Nasabah terhadap Loyalitas Nasabah sebesar 0,339. Hasil ini jika dikalikan (0.897 x 0339) sama dengan 0,304 . Dari perkalian koefisien tersebut dapat disimpulkan bahwa variable Kepuasan Nasabahn tidak berfungsi secara efektif sebagai variable intervening dalam pengaruh Kualitas Pelayanan terhadap Loyalitas Nasabah karena nilai koefisien pengaruh langsung lebih besar dari pengaruh tidak langsung (0,382>0,304).

2). Pengaruh tidak langsung variable Penanganan Komplain terhadap Loyalitas Nasabah melaluiKepuasan Nasabah.

Hasil uji dengan model persamaan regresi pertama dan kedua menunjukkan bahwa pengaruh Penanganan Komplain terhadap Kepuasan Nasabah sebesar -0,087 sedangkan pengaruh Kepuasan Nasabah terhadap Loyalitas Nasabah 0,339. Hasil ini jika dikalikan (-0.087 x 0.339) sama dengan - 0,029. Dari perkalian koefisien tersebut dapat disimpulkan bahwa variable Kepuasan Pelanggan berfungsi secara efektif sebagai variable intervening dalam pengaruh Harga terhadap Loyalitas Pelanggan karena nilai koefisien pengaruh langsung lebih besar dari pengaruh tidak langsung $(0,078>-0,029)$.

3). Pengaruh tidak langsung variable Fasilitas Teknologi terhadap Loyalitas Nasabah melalui Kepuasan Nasabah. Hasil uji dengan model persamaan regresi pertama dan kedua menunjukkan bahwa pengaruh Fasilitas Teknologi terhadap Kepuasan Nasabah sebesar 0,090, sedangkan pengaruh Kepuasan Nasabah terhadap Loyalitas Nasabah sebesar 0,339. Hasil ini jika dikalikan ( 0,090 x 0.339) sama dengan 0,030 . Dari perkalian koefisien tersebut dapat disimpulkan bahwa variable Kepuasan Pelanggan tidak berfungsi secara efektif sebagai variable intervening dalam pengaruh Fasilitas Teknologi terhahadap Loyalitas Nasabah karena nilai koefisien pengaruh langsung lebih besar dari pengaruh tidak langsung $(0,144>0,030)$.

\section{Pengaruh total}

1). Berdasarkan hasil model persamaan regresi pertama dan kedua menunjukkan bahwa pengaruh Kualitas Pelayanan terhadap Loyalitas Nasabah sebesar 0,382, sedangkan pengaruh tidak langsung Kualitas Pelayanan terhadap Loyalitas Pelanggan melalui Kepuasan Pelanggan sebesar 0,304, diperoleh koefisien 0,686. Sehingga pengaruh total variable Kualitas Pelayanan terhadap Loyalitas Nasabah sebesar 0,686.

2). Berdasarkan hasil model persamaan regresi pertama dan kedua menunjukkan bahwa pengaruh Penanganan Komplain terhadap Loyalitas Nasabah sebesar 0,078 sedangkan pengaruh tidak langsung Penanganan Komplain terhadap Loyalitas Nasabah melalui Kepuasan Nasabah sebesar -0,029, diperoleh koefisien -0,216. Sehingga pengaruh total variable Harga terhadap Loyalitas Pelanggan sebesar 0,049.

3). Berdasarkan hasil model persamaan regresi pertama dan kedua menunjukkan bahwa pengaruh Fasilitas Teknologi terhadap Loyalitas Nasabah sebesar 0,144, sedangkan pengaruh tidak langsung Fasilitas Teknologi terhadap Loyalitas Nasabah melalui KepuasanNasabah sebesar 0,030, diperolehkoefisien 0,174. Sehingga pengaruh total variable Promosi terhadap Loyalitas Pelanggan sebesar 0,174. 


\section{Implikasi Manajerial}

1. Kualitas Pelayanan berpengaruh positif dan signifikan terhadap Loyalitas Nasabah. Artinya apabila Kualitas Pelayanan ditingkatkan maka loyalitas nasabah akan meningkat.Dalam usaha meningkatkan Loyalitas Nasabah, Kualitas pelayanan dapat ditingkatkan dengan cara :

a. Peningkatan kecepatan dalam pelayanan.

b. Peningkatan penjelasan informasi secara detail.

c. Peningkatan tanggapan terhadap keluhan serta pemberian solusi.

2. Penanganan Komplain berpengaruh positif dan signifikan terhadap Loyalitas Pelanggan. Artinya apabila penanganan komplain ditingkatkan maka loyalitas nasab akan meningkat.Dalam usaha peningkatan Loyalitas nasabah bisa dilakukan dengan meningkatka penanganan komplain dengan cara:

a. Peningkatan kemudahan prosedur penanganan komplain.

b. Peningkatan kepuasan nasabah dalam penanganan komplain.

c. Peningkatan kecepatan dalam penanganan komplain.

3. Faslitas Teknologi berpengaruh positif dan signifikan terhadap loyalitas nasabah. Apabila fasilitas teknologi ditingkatkan maka loyalitas nasabah akan meningkat. Peningkatan fasilitas teknologi bisa dilakukan dengan cara :

a. Peningkatan kecepatan transaksi dengan internet banking.

b. Pengurangan biaya internet banking.

c. Peningkatan fasilitas transaksi dalam internet banking.

4. Kepuasan Nasabah berpengaruh positif dan signifikan terhadap Loyalitas nasabah. Apabila Kepuasan nasabah ditingkatkan maka loyalitas nasabah akan meningkat. Kebijakan peningkatan Loyalitas nasabah bisa dilakukan dengan meningkatkan Kepuasan nasabah dengan cara :

a. Peningkatan peralatan yang digunakan dalam pelayanan nasabah.

b. Peningkatan fasilitas yang ada.

c. Peningkatan pelayanan yang diberikan pegawai kepada nasah.

5. Penelitian menunjukkan bahwa Kepuasan Pelanggan tidak dapat dijadikan sebagai variable intervening pada hubungan Kualitas Pelayanan, Penanganan Komplain, dan fasilitas teknologi terhadap loyalitas nasabah.

\section{PENUTUP}

\section{Simpulan}

Berdasarkan hasil analisa data dan Pengujianhipotesis yang telah dilakukan dapat ditarik kesimpulan :

1. Hasil analisis regresi:

a. Persamaan pertama :Kualitas pelayanandan Fasilitas Teknologi berpengaruh positif terhadap Kepuasan Nasabah,sedangkan Penangan Komplain berpengaruh negatif terhadap Kepuasan Nasabah.

b. Persamaan Kedua :Kualitas Pelayanan, Penanganan Komplain, dan Kepuasan nasabah berpengaruh positif terhadap Loyalitas Nasabah.

2. Secara individual pengujian terhadap hipotesis penelitian (Uji t) menunjukkan bahwa:

a. Kualitas Pelayanan, Penanganan Komplain dan fasilitas Teknologi berpengaruh signifikan terhadap Kepuasan Nasabah.

b. Kualitas Pelayanan, Penanganan Komplain, Fasilitas Teknologi, dan Kepuasan Nasabah berpengaruh signifikan terhadap Loyalitas Nasabah.

3. Berdasarkan uji F dapat disimpulkan secara bersama-sama variabel Kualitas Pelayanan, Penanganan Komplain,

Fasilitas Teknologi, dan Kepuasan Nasabah berpengaruh signifikan terhadap Loyalitas Nasabah.

4. Berdasarkan uji determinsi diperoleh total $\mathrm{R}^{2}$ sebesar 0,8872 atau 88,72\%, artinya model dengan persamaan ini variable independen (Kualitas Pelayanan, Penanganan Komplain, Fasilitas Teknologi, dan Kepuasan Nasabah mampu menjelaskan variable dependen (Loyalitas Pelanggan) sebesar 88,72\% sisanya sebesar 11,28\% dijelaskan oleh variable lain di luar model seperti : ikatan emosi, Kepercayaan, Kemudahan transaksi.

5. Hasil uji dengan analisa jalur menunjukkan bahwa Kepuasan Nasabahtidak dapat dijadikan sebagai variable intervening pada hubungan Kualitas Pelayanan, Penanganan Komplain, Fasilitas Teknologi terhadap Loyalitas Nasabah. 


\section{B. SARAN}

Berdasarkan kesimpulan diatas, peneliti menyarankan bahwa dalam menentukan kebijakan peningkatan Loyalitas Nasabah Bank Mandiri Syariah Cabang Solo disarankan :

1. Kualitas pelayanan dapat ditingkatkan ngan cara :

a. Peningkatan kecepatan dalam pelayanan.

b. Peningkatan penjelasan informasi secara detail.

c. Peningkatan tanggapan terhadap keluhan serta pemberian solusi.

2.Peningkatna penanganan komplain bisa dilakukan dengan cara:

a. Peningkatan kemudahan prosedur penanganan komplain.

b. Peningkatan kepuasan nasabah dalam penanganan komplain.

c. Peningkatan kecepatan dalam penanganan komplain.

3. Peningkatan fasilitas teknologi bisa dilakukan dengan cara :

a. Peningkatan kecepatan transaksi dengan internet banking.

b. Pengurangan biaya internet banking.

c. Peningkatan fasilitas transaksi dalam internet banking.

4. Peningkatan Kepuasan nasabah dengan cara :

a. Peningkatan peralatan yang digunakan dalam pelayanan nasabah.

b. Peningkatan fasilitas yang ada.

c. Peningkatan pelayanan yang diberikan pegawai kepada nasabah.

\section{DAFTAR PUSTAKA}

Arikunto, Suharsimi. 2006. Metode Penelitian. Rineka Cipta. Jakarta

Assael H. 2006. Consumers Behavior and Marketing Action, Boston Massachusset, AS. Kent Publishing Company.

Azwar. 2007. Metode Penelitian. Penerbit Rineka Cipta. Jakarta

Basu, Swastha, Dharmmesta. Hani, Handoko. 2008. Manajemen Pemasaran Analisis. Perilaku Konsumen Edisi Pertama. Yogyakarta: BPFE

Dharmmesta. Hani, Handoko. 2008. Manajemen Pemasaran Analisis. Perilaku Konsumen Edisi Pertama. Yogyakarta: BPFE

Didik Kurniawan. 2013. Pengaruh Kualitas Layanan, Kualitas Produk dan Nilai Nasabah terhadap kepuasan dan Loyalitas Nasabah pada Bank BPD DIY Yogyakarta. Skripsi UIN Sunan Kalijaga Yogyakarta

Ghozali, Imam. 2005. Aplikasi Analisis Multivariate dengan SPSS.Semarang : Undip Semarang Kasmir, (2004). Bank dan Lembaga Keuangan Lainnya. Jakarta : PT. Raja. Grafindo Persada. Keputusan Menpan Nomor 25 Tahun 2004

Kotler Philip. 2005. “Dasar-Dasar Pemasaran" Prenhallindo . Jakarta

Kotler, Philip. 2009. Manajemen Pemasaran. Jakarta : Erlangga

Mowen. H. 2006. Perilaku Konsumen. Jilid I. Penerbit. Andi. Yogyakarta.

Oliver David L., 2009, Consumer Behavior: Building Marketing Strategy, Eleventh Edition, New York: McGraw-Hill International Edition

Rangkuti, Freddy. 2007. Measuring Customer satisfaction.Jakarta. PT Gramedia Pustaka Utama

Setiaji. 2008. Cara Mudah Analisis Kuantitatif Dilengkapi DenganTutorial SPSS. Surakarta: Al-Es'af University Press 
Sugiyono. (2008). Statistik Penelitian. (Edisi Revisi). Alfabeta Jakarta

Suharyadi dan Purwanto. 2004. Statitistika Untuk Ekonomi \& Keuangan Modern, Jakarta : Salemba Empat

Swasta dan T Hani Handoko. 2008. Manajemen Pemasaran Analisa Perilaku Konsumen. Yogyakarta : BPFE

Tjiptono, Fandy. 2005. Strategi Pemasaran. Edisi Kedua. Cetakan Keenam. Penerbit. Andy. Yogyakarta

Tjiptono, Fandy dan Gregorius Chandra. 2005. Service, Quality \&Satisfaction. Yogyakarta :Andi Offset

Umar, Husein. 2005. Metode Penelitian, Jakarta : Ghalia Indonesia.

Wiwi Widiyah. 2012. Pengaruh Kualitas Pelayanan dan Kelengkapan Fasilitas terhadap Kepuasan Nasabah pada Bank Muamalat Indonesia Cabang Cirebon. Skripsi IAIN Syekh Nurjati Cirebon.

Yuda Supriyanto. 2012. Analisis Pengaruh Kualitas Pelayanan, Harga dan Fasilitas Terhadap Kepuasan Pasien Rawat Jalan di Rumah Sakit Kariadi Semarang. Skripsi Universitas Diponegoro Semarang.

Yunus dan Budiman. 2014. Pengaruh Kualitas Pelayanan Dan Fasilitas Terhadap Kepuasan Pelanggan Di Narita Hotel Surabaya.Jurnal Ilmu \& Riset Manajemen Vol. 3 No. 12 (2014).

Zeithaml, Valerie A. Dan Bitner. 2006. Service Marekting 2nd Edition : Integrating Customer Focus. New York : Mc Graw Hill Inc. 